CZASOPISMO INŻYNIERII LĄDOWEJ, ŚRODOWISKA I ARCHITEKTURY JOURNAL OF CIVIL ENGINEERING, ENVIRONMENT AND ARCHITECTURE

JCEEA, t. XXXIII, z. 63 (3/16), lipiec-wrzesień 2016, s. 113-122

\author{
Marian HOLUB \\ Magdalena BALINTOVA ${ }^{2}$ \\ Stefan DEMCAK ${ }^{3}$ \\ Maria HURAKOVA ${ }^{4}$
}

\title{
CHARACTERIZATION OF NATURAL ZEOLITE AND DETERMINATION ITS ADSORPTION PROPERTIES
}

\begin{abstract}
Pollution of water by toxic substances is one of the major reason concerning human health as well as the environmental quality. In terms of pollution, mining activities represent a serious threat. Countries of the middle Europe, where extraction of mineral resources takes place a long period, have to solve the problems of wastewater containing whole spectra of heavy metals, which are dangerous to the environment. Finding of the new and cheap ways of wastewater contaminated by heavy metals treatment can increase the quality of the environment in the affected localities and thus prevent adverse effects on fauna, flora or human beings. Sorption techniques belong to a cost effective methods that are able to effectively remove heavy metals. For the overall understanding of the sorption process, it is necessary to characterize and determine the properties of the used adsorbents. The paper deals with characterization of natural zeolite before and after sorption process under acidic conditions. The zeolite was characterized using Fourier transform infrared spectroscopy, $\mathrm{X}$ - ray diffraction, scanning electron microscopy and $\mathrm{N}_{2}$ adsorption/desorption isotherms.
\end{abstract}

Keywords: zeolite, sorption, XRF, XRD, SEM, specific surface area

\section{Introduction}

The development of human society after $18^{\text {th }}$ century is associated with metals. Technology of extraction and processing of heavy metals is essential for

\footnotetext{
${ }^{1}$ Marian Holub, Technical University of Kosice, Faculty of Civil Engineering, Institute of Environmental Engineering, Vysokoskolska 4, 04200 Kosice, Slovakia, +421556024154, marian.holub@tuke.sk

2 Magdalena Balintova, Technical University of Kosice, Faculty of Civil Engineering, Institute of Environmental Engineering, Vysokoskolska 4, 04200 Kosice, Slovakia, magdalena.balintova@tuke.sk

${ }^{3}$ Stefan Demcak, Technical University of Kosice, Faculty of Civil Engineering, Institute of Environmental Engineering, Vysokoskolska 4, 04200 Kosice, Slovakia, stefan.demcak@tuke.sk

${ }^{4}$ Maria Hurakova, Slovak Academy of Science, Institute of Experimental Physics, Watsonova 47, 04001 Kosice, Slovakia, hurakova@saske.sk
} 
many areas of industry. Naturally, the extraction, processing and cleaning of impurities give the metals not only a new form, but also cause their intensive distribution in the environment, which represents a huge threat.

Ion-exchange sorption is one of the basic process technologies of liquid waste, in which the fixing of metal cations in the suitable form for deposition in the storage site is ensured [1]. Finding of cheap and efficient materials from natural resources is therefore necessary.

Natural zeolites are hydrated aluminosilicate minerals of a porous structure with valuable physicochemical properties, such as cation exchange, molecular sieving, catalysis and sorption [2]. The sorption properties of the zeolites had been known for the decades. After the large - scale application of x-ray powder diffraction in the second half of $20^{\text {th }}$ century a huge reserves of zeolites began to appear and subsequently have been studied and utilized as adsorbents for the removal of heavy metals in many countries [3], [4] and [5].

The aim of this study was to investigate possibilities of application of Slovak natural zeolite for removal of heavy metal ions from aqueous solutions. In specific, $\mathrm{Cu}(\mathrm{II})$ was selected as a model ion due to common presence of this cation in the acid mine drainage. Zeolite was also characterized using different methods in order to determine the changes caused by adsorption/ion - exchange process.

\section{Materials and methods}

\subsection{Zeolite samples preparation}

In this study a natural non - modified zeolite from locality of Nizny Hrabovec (Slovakia) was used. The different fractions were prepared by milling of commercial product with granularity of 2.5 to $5 \mathrm{~mm}$ (Zeocem, a.s.; Bystre, Slovakia) by planetary mill (Desk - top planetary ball Miller SFM-1) at $290 \mathrm{rpm}$ (tray rotating) and $580 \mathrm{rpm}$ (grinding jars rotating) for $18 \mathrm{~min}$. After that sieve analysis for the purpose of separation of different fractions was performed. Sieves were shaken in a mechanical shaker for 10 minutes to provide complete separation. The separated fraction of zeolite was washed in deionized water in order to eliminate eventually present dust. Samples were dried at $105^{\circ} \mathrm{C}$ for $17 \mathrm{~h}$ and then allowed to cool in the desiccators before their using in experiments.

\subsection{Apparatus and instrumentation}

- A Colorimeter DR890 (HACH LANGE, Germany) with appropriate reagent was used to determine amount of dissolved $\mathrm{Cu}(\mathrm{II})$.

- The basic chemical composition of zeolite was investigated by X-ray fluorescence analysis (XRF) using SPECTRO iQ II (Ametek, Germany) with SDD silicon drift detector with resolution of $145 \mathrm{eV}$ at 10000 pulses. 
- IR spectra were measured by Alpha FT-IR Spectrometer with ALPHA's Platinum ATR single reflection diamond ATR module (Bruker, Germany).

- Mineralogical analysis of the natural zeolite samples was carried out by X-Ray Diffraction (XRD) using diffractometer Bruker D2 Phaser (Bruker AXS, $\mathrm{GmbH}$, Germany) in Bragg-Brentano geometry (configuration Theta-2Theta), using the $1.54060 \AA \mathrm{CuK} \alpha$ radiation, $\mathrm{Ni} \mathrm{K} \beta$ filters and scintillation detector at a voltage of $30 \mathrm{kV}$ and $10 \mathrm{~mA}$ current. Scan conditions: recording time about 4.5 hours, a step size of $0.02^{\circ}(2 \Theta)$ and step time of $5 \mathrm{~s}$. The XRD patterns were processed using the software Diffrac.EVA v. 2.1. The ICDD PDF database (ICDD PDF - 2 Release 2009) was utilized for the phase identification.

- SEM (Tescan - VEGA3 LMU) with EDX analysis (Bruker, Germany) was used for determination of composition and structure of the zeolite surface.

- Specific surface area was estimated by low temperature gas adsorption using nitrogen gas (Quantachrome NOVA 1000e, USA).

\subsection{Adsorbate solution preparation}

Synthetic solutions of $\mathrm{Cu}$ (II) were prepared from $\mathrm{CuSO}_{4} \cdot 5 \mathrm{H}_{2} \mathrm{O}$ (A.R.). Working solutions were prepared by further dilution to the desired initial concentration $(50 \mathrm{mg} / \mathrm{L})$. The initial $\mathrm{pH}$ of each solution was adjusted to the required value $(\mathrm{pH} \approx 4)$ by adding $0.001 \mathrm{M} \mathrm{H}_{2} \mathrm{SO}_{4}$. It should be noted that sulphate anions are not forming precipitates or complexes with copper cations at the test conditions and are considered to be inert.

\subsection{Batch adsorption experiment}

For the purpose of removal efficiency investigation and also preparation of zeolite sample with adsorbed cations, batch adsorption experiment was carried out. Zeolite (fraction below $0.063 \mathrm{~mm}$ ) was mixed with single-component solutions containing $50 \mathrm{mg} / \mathrm{L}$ of $\mathrm{Cu}(\mathrm{II})$. Batch experiments were carried out at room temperature $\left(23 \pm 0.2^{\circ} \mathrm{C}\right)$ in beakers, batch rate: $1 \mathrm{~g}$ of zeolite per $100 \mathrm{~mL}$ of solution. After 24 hours reaction time, sorbents were removed by filtration through a laboratory filter paper for qualitative analysis and residual concentration of copper was determined by colorimetric method. Used zeolite was separated and dried at $105{ }^{\circ} \mathrm{C}$ for $17 \mathrm{~h}$ and then allowed to cool in the desiccators before their further characterization.

\subsection{Fixed - bed adsorption experiment}

Fixed - bed column used in this study was made of Pyrex glass tube with the inner and outer diameters of 4.0 and $4.5 \mathrm{~cm}$, respectively ended by coarse porosity fritted glass disc. A known quantity $(50 \mathrm{~g})$ of the zeolite $(1-2 \mathrm{~mm}$ and $2-4 \mathrm{~mm}$, respectively) was packed in the column to yield a bed height of $4 \mathrm{~cm}$. 
Solution containing copper of $50 \mathrm{mg} / \mathrm{L}$ flowed by gravity downward through the column at a filtration velocities of 0.3 and $1.3 \mathrm{~mL} / \mathrm{sec}$ (for $1-2 \mathrm{~mm}$ and $2-4$ $\mathrm{mm}$ fraction, respectively), controlled by a couple of valves. The effluents at the outlet of the column were collected at regular time intervals and the $\mathrm{Cu}$ (II) concentrations were measured using colorimetric method. All experiments were performed at room temperature $\left(23 \pm 0.2^{\circ} \mathrm{C}\right)$.

\section{Results}

\subsection{Characterization of natural zeolite}

In order to determine the basic characteristics of natural zeolite and changes after the sorption process several measurements were carried out. The results from X-ray fluorescence (XRF) analysis, X-Ray Diffraction (XRD), Infrared spectroscopy (FTIR), scanning electron microscopy (SEM) and specific surface area (SSA) measurements are presented.

\subsubsection{XRF}

XRF analysis was used to determine of chemical composition of zaolite samples. The chemical composition of the zeolite declared by the manufacturer (Zeocem, a.s.) and results from X-ray fluorescence analysis are listed in Table 1.

Table 1. Chemical composition of zeolite (declared data by manufacturer and results of XRF analysis)

Tabela 1. Skład chemiczny zeolitu (podawany przez producenta oraz wyniki analizy XRF)

\begin{tabular}{|c|c|c|c|c|c|c|c|c|}
\hline Constituent & $\mathbf{S i O}_{\mathbf{2}}$ & $\mathbf{A l}_{\mathbf{2}} \mathbf{O}_{\mathbf{3}}$ & $\mathbf{C a O}$ & $\mathbf{K}_{\mathbf{2}} \mathbf{O}$ & $\mathbf{F e}_{\mathbf{2}} \mathbf{O}_{\mathbf{3}}$ & $\mathbf{M g O}$ & $\mathbf{N a}_{\mathbf{2}} \mathbf{O}$ & $\mathbf{T i O}_{\mathbf{2}}$ \\
\hline $\begin{array}{c}\text { Declared content } \\
\text { (mass \%) }\end{array}$ & $\begin{array}{c}65.00 \\
-\end{array}$ & $\begin{array}{c}11.50 \\
-\end{array}$ & $\begin{array}{c}2.70- \\
5.20\end{array}$ & $\begin{array}{c}2.20- \\
13.10\end{array}$ & $\begin{array}{c}0.70 \\
-\end{array}$ & $\begin{array}{c}0.60- \\
1.20\end{array}$ & $\begin{array}{c}0.20- \\
1.30\end{array}$ & $\begin{array}{c}0.10- \\
0.30\end{array}$ \\
\hline $\begin{array}{c}\text { XRF analysis } \\
\text { (mass \%) }\end{array}$ & 64.10 & 9.89 & 2.99 & 2.71 & 1.34 & 0.73 & - & 0.15 \\
\hline
\end{tabular}

\subsubsection{XRD}

Mineralogical analysis of the natural zeolite samples (before and after sorption) was carried out using X-Ray Diffraction. The results showed that the natural zeolite contained clinoptilolite in the majority, and small quantities of silicon oxides (cristobalite and quartz), feldspar and illite (see Fig. 1). From the pattern is also evident that the sorption does not affect the mineralogical structure; patterns are identical. 


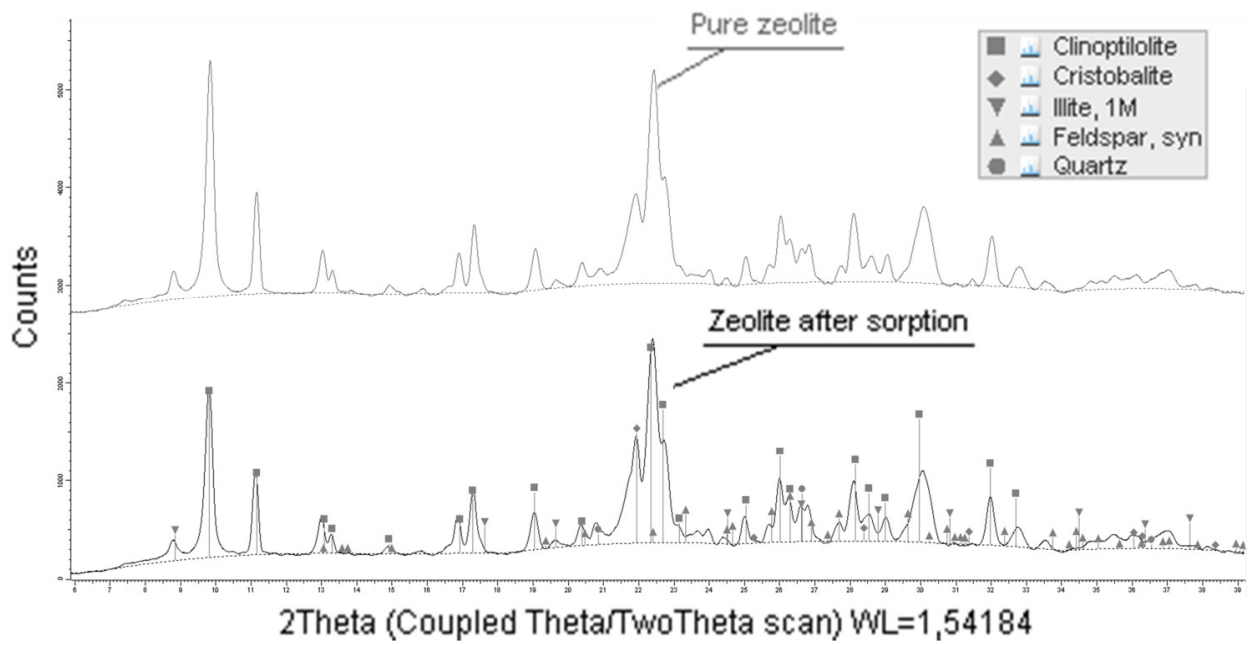

Fig. 1. X-ray diffraction analysis of zeolite

Rys. 1. Rentgenowska dyfrakcyjna analiza zeolitu

\subsubsection{FTIR}

The characterization of zeolites by FTIR technique is based on the presence of bands in three regions. A higher one corresponds to the $\mathrm{OH}$ stretching modes $\left(3650-3450 \mathrm{~cm}^{-1}\right)$ with an additional band at $1620-1640 \mathrm{~cm}^{-1}$ (Lewis sites).

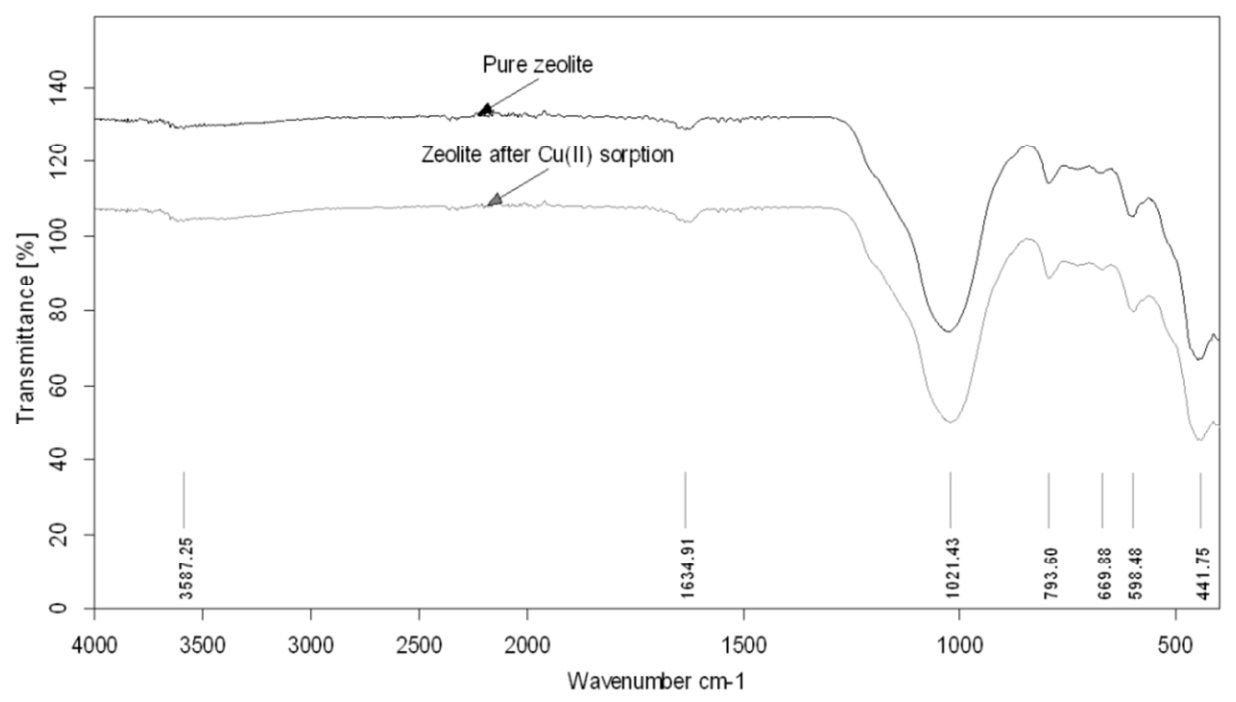

Fig. 2. Infrared spectra

Rys. 2. Spektrum podczerwieni 
This region is assigned $\mathrm{H}-\mathrm{O}-\mathrm{H}$ bending of the water molecules (zeolitic water) in channels of the samples [6]. The middle zone $\left(1200-900 \mathrm{~cm}^{-1}\right)$ is characterized by strong bands attributed basically to the $\mathrm{TO}_{4}(\mathrm{~T}=\mathrm{Al}, \mathrm{Si})$ stretching modes whereas the corresponding bending modes of the $3 \mathrm{D}$ covalent arrangement are observed below $700 \mathrm{~cm}^{-1}$ [7].

As it is seen in Fig. 2, there is no difference between IR spectrum of pure zeolite and after sorption of copper thus there are not changes in chemical structure and also the precipitate is not present.

\subsubsection{SEM}

Characterization of structure and morphology of zeolite was observed by SEM with EDX. Fig. 3 represents the morphology of particulate substances of zeolite (left: pure zeolite; right: zeolite after sorption). As is shown in this figure, the structure is almost identical in both samples.

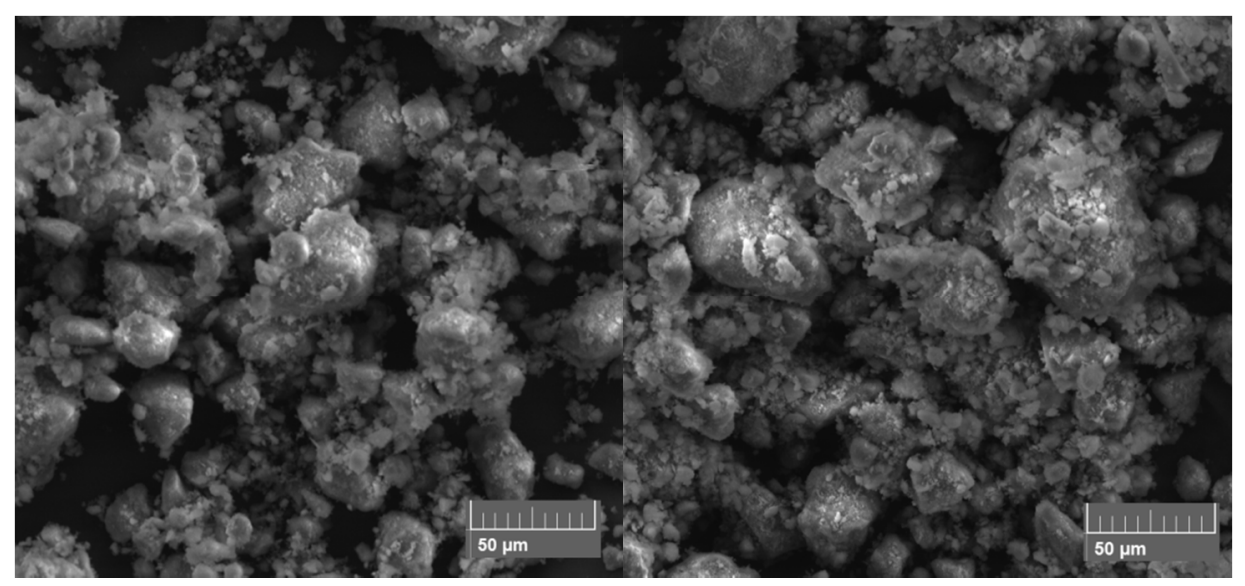

Fig. 3. Structure of zeolite (left: before sorption; right: after sorption)

Rys. 3. Struktura zeolitu (z lewej: przed sorpcją; po prawej: po sorpcji)

The presence of $\mathrm{Cu}(\mathrm{II})$ on the surface of zeolite after the sorption has been proved by energy dispersive microanalysis (see results in Table 2.) According to ion - exchange background of the process, it can be observed a little decrease in concentration of exchangeable cations $(\mathrm{K}, \mathrm{Mg}, \mathrm{Ca})$ after the sorption process. 
Table 2. Chemical composition of zeolite by SEM/EDX

Tabela 2. Skład chemiczny zeolitu - SEM/EDX

\begin{tabular}{c|cccccccc}
\hline \multicolumn{10}{c}{ Average ratio of elements in samples [\%] } \\
\hline Element & $\mathbf{O}$ & $\mathbf{S i}$ & $\mathbf{K}$ & Al & $\mathbf{M g}$ & $\mathbf{F e}$ & $\mathbf{C a}$ & $\mathbf{C u}$ \\
\hline Pure zeolite & 38.8 & 38.2 & 5.2 & 7.7 & 0.3 & 5.2 & 4.6 & - \\
\hline $\begin{array}{c}\text { Zeolite after } \\
\text { sorption }\end{array}$ & 38.1 & 40.0 & 4.7 & 7.9 & 0.2 & 4.4 & 3.2 & 1.07 \\
\hline
\end{tabular}

\subsubsection{Specific surface area}

One of the many properties used to characterize adsorbents is the specific surface area (SSA). SSA plays important role in adsorption process; however there are other mechanisms that can influence the progress of adsorption (e.g. ion-exchange abilities, complexation, chelation, etc.).

In order to evaluate the influence of grinding estimation of SSA of different zeolite fractions by physisorption of nitrogen gas at $77 \mathrm{~K}$ according to the BET method was carried out. Degassing of zeolite was carried out with respect of their thermal stability determined by thermal analyzer (Netzsch STA 449 F3, Germany). The results are presented in Table 3.

Table 3. Specific surface areas of different zeolite fractions

Tabela 3. Powierzchnia właściwa różnych frakcjach zeolitu

\begin{tabular}{c|ccc} 
& $\mathbf{2}-\mathbf{4} \mathbf{~ m m}$ & $\mathbf{1 - 2} \mathbf{~ m m}$ & below $\mathbf{0 . 0 6 3} \mathbf{~ m m}$ \\
\hline $\begin{array}{c}\text { SSA } \\
\left(\mathbf{m}^{2} / \mathbf{g}\right)\end{array}$ & 24.97 & 27.61 & 28.35
\end{tabular}

As can be seen, the differences between fractions are minimal, in addition another measurement of the zeolite sample after the sorption process was also carried out. Despite after the $90 \%$ efficiency of copper removal, the change in specific surface area was not observed. This facts show us an indication of the ion - exchange background of the process. From the shape of adsorption/desorption curves (Fig. 4) it can be said, that the zeolite exhibit microporous structure with the pore size predominantly under $1 \mathrm{~nm}$. 


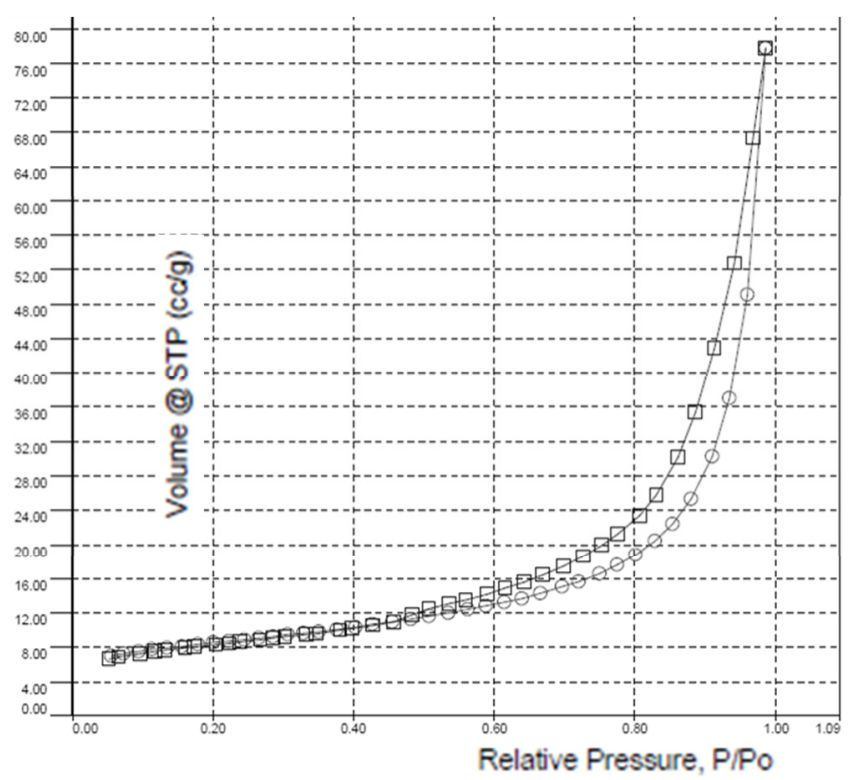

Fig. 4. Adsorption/desorption curves of zeolite (fraction under $0.063 \mathrm{~mm}$ )

Rys. 4. Adsorpcja/desorpcja zeolitu (frakcja poniżej $0,063 \mathrm{~mm}$ )

\subsection{Batch experiment}

Batch adsorption experiment was performed in order to evaluate sorption efficiency of zeolite in static conditions. The percentage adsorption (\%) was calculated using the following equation:

$$
\% \text { Adsorption }=\frac{\left(C_{0}-C_{e}\right)}{C_{0}} \times 100 \%
$$

where, $C_{0}$ is the initial concentration of copper ions $(\mathrm{mg} / \mathrm{L})$ and $C_{e}$, equilibrium concentration of copper ions $(\mathrm{mg} / \mathrm{L})$. Zeolite exhibit efficiency around $90 \%$ after $24 \mathrm{~h}$ contact time with batch rate of $1 \mathrm{~g} / 100 \mathrm{~mL}$.

\subsection{Fixed - bed column experiments}

Adsorption of copper by zeolite is presented in the form of breakthrough curves (Figure 5). According to the results of previous experiments with $2-4$ $\mathrm{mm}$ fraction, flow rate of $1.3 \mathrm{~mL} / \mathrm{sec}$ is too high, since breakthrough occurs faster and with less sharpened boundaries. It was necessary to reduce the flow rate using the smaller fraction of zeolite which has proved as a successful approach (see Fig. 5).

Lower flow rate results in high residence times in the column. It is well known that, because of the relatively slow loading kinetics of zeolites, relatively 


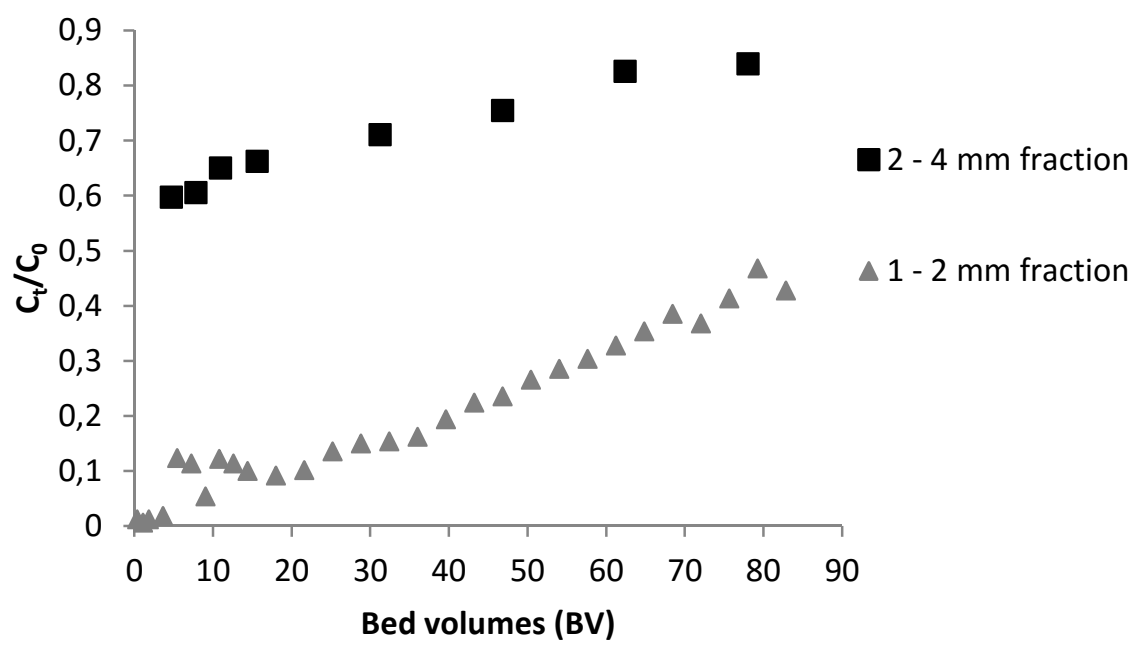

Fig. 5. Breakthrough curves of column experiments for $\mathrm{Cu}(\mathrm{II})$ at initial concentration of $50 \mathrm{mg} / \mathrm{L}$

Rys. 5. Krzywe przebicia dla Cu (II) przy początkowym stężeniu $50 \mathrm{mg} / \mathrm{l}$

long residence times are needed [8]. In addition it is well known that decreasing in particle size improves the performance of adsorption and ion exchange [9]. This improvement is due to the extension of surface area (see Table 3 ) and better access to easily removable exchangeable cations in the zeolite structure.

\section{Conclusions}

Natural zeolites are important low cost and wide available materials for water and wastewater treatment. Due to the nature of cation exchange, zeolites exhibit high performance in adsorption of different cations in aqueous solution.

In this study, the natural zeolite (clinoptilolite) from Slovakia (Nizny Hrabovec) was characterized using different methods. A batch and fixed - bed systems were used to describe the adsorption properties. The efficiency of $\mathrm{Cu}$ (II) sorption was at satisfactory level (90\% for the batch system and $60 \%$ after 80 batch volumes in the dynamic conditions), in addition the competitive adsorption in the process of ion - exchange between copper and hydrogen cations was observed.

Overall, from the results of this study imply that the adsorption under acidic condition does not affect the structure of zeolite. As a result of ion - exchange only one change in chemical composition using by SEM/EDX was observed.

\section{Acknowledgement}

This work has been supported by the Slovak Grant Agency for Science (Grant No. 1/0563/15) and the project No. 26210120012 provided by the European Social Fund. 


\section{Bibliography}

[1] Foldesová M., Hudec P. Štúdium povrchových vlastností slovenského prírodného zeolitu - klinoptilolitu fyzikálnou adsorpciou dusíka. Petroleum \& Coal, vol. 49, no 1, pp. 34-40, 2007.

[2] El-Kamash A.M. Evaluation of zeolite A for the sorptive removal of $\mathrm{Cs}+$ and $\mathrm{Sr} 2+$ ions from aqueous solutions using batch and fixed bed column operations. Journal of. Hazardous Materials, vol. 151, issues 2 - 3, pp. 432-445, 2008.

[3] Baker H.M., Massadeh A.M., Younes H.A. Natural Jordanian zeolite: removal of heavy metal ions from water samples using column and batch method. Environmental Monitoring and Assessment. vol. 157, issues 1 - 4, pp. 319-330, 2009.

[4] Hamidpour M., Kalbasi M., Afyuni M., Shariatmadari H., Holm P.E., Hansen H.C.B. Sorption hysteresis of $\mathrm{Cd}(\mathrm{II})$ and $\mathrm{Pb}(\mathrm{II})$ on natural zeolite and bentonite. Journal of Hazardous Materials, vol. 181, issues 1-3, pp. 686-691, 2010.

[5] Wang S., Peng Y. Natural zeolites as effective adsorbents in water and wastewater treatment. Chemical Engineering Journal, vol. 156, issue 1, pp. 11-24, 2010.

[6] Zhao D., Zhou J., Liu N. Preparation and characterization of Mingguang palygorskite supported with silver and copper for antibacterial behavior. Applied Clay Science, vol. 33, pp. $161-170,2006$.

[7] Van der Marel H.W., Beutelspacher H. Atlas of Infrared Spectroscopy of Clay Minerals and their admixtures. Elsevier, USA, 1976.

[8] Burn P. Design and testing of natural/blended zeolite ion exchange columns at West Valley. AlChE Symp. Ser., vol. 83, pp. 66 - 72, 1987.

[9] Helfferich F. Ion Exchange. Dover Publications Inc., New York, 1995.

\section{CHARAKTERYSTYKA NATURALNYCH ZEOLITÓW ORAZ OKREŚLENIE ICH WŁAŚCIWOŚCI ADSORPCYJNYCH}

\section{Streszczenie}

Zanieczyszczenie wód substancjami toksycznymi znacząco wpływa na zdrowie ludzkiego, a także jakość środowiska. Pod względem zanieczyszczenia, działalność górnicza stanowi poważne zagrożenie. Kraje środkowej Europy, gdzie wydobycie zasobów mineralnych występuje przez długi okres czasu, narasta problem ścieków zawierających całe spektrum metali ciężkich, które są niebezpieczne dla środowiska. Znalezienie nowych i tanich sposobów oczyszczania ścieków zanieczyszczonych metalami ciężkimi, może wpłynąć na poprawę jakości środowiska w dotkniętych zanieczyszczeniem miejscowościach, a tym samym zapobiec niekorzystnemu oddziaływaniu na faunę, florą oraz człowieka. Techniki sorpcyjne należą do efektywnych pod względem kosztów metod, które są w stanie skutecznie usunąć metale ciężkie. Dla ogólnego zrozumienia procesu sorpcji, konieczne jest scharakteryzowanie i określenia właściwości stosowanych adsorbentów. W pracy przedstawiono charakterystykę naturalnych zeolitów, przed i po procesie sorpcji w warunkach kwaśnych. Zeolit scharakteryzowano za pomocą spektroskopii w podczerwieni z transformacją Fouriera, X - ray dyfrakcji elektronowej mikroskopii skaningowej i izoterm $\mathrm{N}_{2}$ adsorpcji/desorpcji.

Słowa kluczowe: zeolit, sorpcja, XRF, XRD, SEM, powierzchnia właściwa

DOI:10.7862/rb.2016.192

Przestano do redakcji: $15.09 .2016 r$.

Przyjęto do druku: 30.11.2016 r. 